\title{
環境に配慮したタイヤ用材料技術
}

\author{
原祐一・桐 野 美 昭
}

\section{Environmental Compound Technology for Tires}

Yuichi HARA, Yoshiaki KIRINO (Research and Development Department, THE YOKOHAMA RUBBER Co., LTD. 2-1 Oiwake, Hiratsuka, Kanagawa 254-8601, Japan)

Usage of silica is an important compounding technology contributing to the improvement of vehicle fuel efficiency. Yokohama Rubber has been developed new material that has an environmental contribution by keeping low rolling resistance of tires, reducing tire weight and conservation of material resources. This paper reviews recent technology of silica compound and new material technology for tire inner liner.

Key Words : Silica, New Material, Fuel Efficiency, Environment

\section{1.は じ めに}

近年，地球温暖化防止の観点から車の燃費向上が世界的 な課題として加速化する中，タイヤ業界においては低燃費 タイヤの開発・商品化の動きが活発になっている．特に国 内では 2010 年度に，共通指針によるグレーディングで夕 イヤの転がり抵抗 (環境性能) とウェット制動（安全性能） をユーザーに示すための，タイヤのラベリング制度がス夕 一トしており，一層の性能向上と幅広い商品展開が求めら れている．材料における低燃費化技術の中心はタイヤトレ ッドゴムへのシリカ配合技術であるが，当社では低燃費夕 イヤの性能を維持する目的で独自にインナーライナーに着 目し，新素材の開発と商品展開を行ってきた。本稿では夕 イヤの低燃費化技術および, 新素材技術について概説する.

\section{2. タイヤの低燃費化技術}

タイヤの低燃費化は, タイヤ構造の最適化, 各部材の物 性改良などにより達成されてきている。図1は夕イヤ断面 構造, 各部材の役割, 概算ではあるが転がり抵抗への寄与 率1)をあらわしたものである。低燃費材料の改良手法と

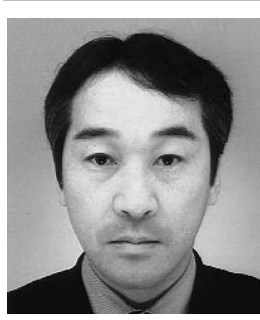

原 祐一; 横浜ゴム(株)研究本部研究部（２548601 神奈川県平塚市追分 2-1)，グループリー ダー. 平成 8 年, 富山大学工学科物質工学専攻, 修了。同年, 横浜ゴム株入社, 現在に至る。 専門は，ゴム，樹脂材料技術.
しては，タイヤ走行中に受ける変形エネルギーを熱エネル ギーとして散逸させない「低発熱化技術開発」と, 変形を 受ける部材の体積低減, つまり「薄肉化・軽量化」を実現 するための物性向上技術（例えば，高モジュラス・強勒・ 耐摩耗の他に，インナーライナーであればガスバリア性向 上）が挙げられる，後者は，省資源という点でも有効な手 法である。

\section{1 低燃費タイヤ用材料の変遷}

低燃費タイヤ用材料の主要な変遷を表 1 に示す。低燃費 タイヤ用材料は，転がり抵抗への寄与率の約半分近くを有 するトレッド部の改良に関わる技術開発を中心に進んでき た.トレッド部を単純に低発熱化すること自体は，低 $T_{\mathrm{g}}$ の ポリマーを選択すること, 補強性の低いフィラーを少量配 合することで実現可能であるが，一方で，路面との摩擦力 や耐摩耗性の悪化を引き起こす。これら背反する特性を同 時に改良し得る原料の開発が進められ，現在も続いている.

\section{2 ポリマー}

背反する特性を両立するためには, より精密な分子設計

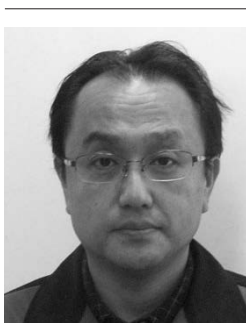

桐野 美昭; 横浜ゴム(株)研究本部研究部（† 254-8601 神奈川県平塚市追分2-1），グループリ ーダー. 平成 6 年, 東京工業大学高分子工学専 攻, 修士課程終了。同年, 横浜ゴム(株)入社, 現在に至る。専門は，ゴム材料技術。 


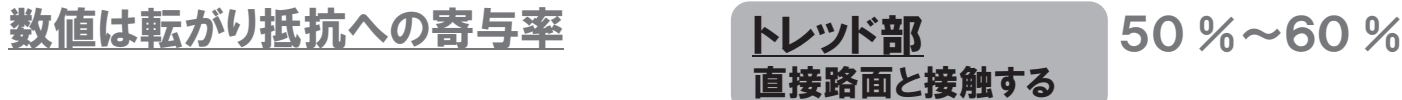

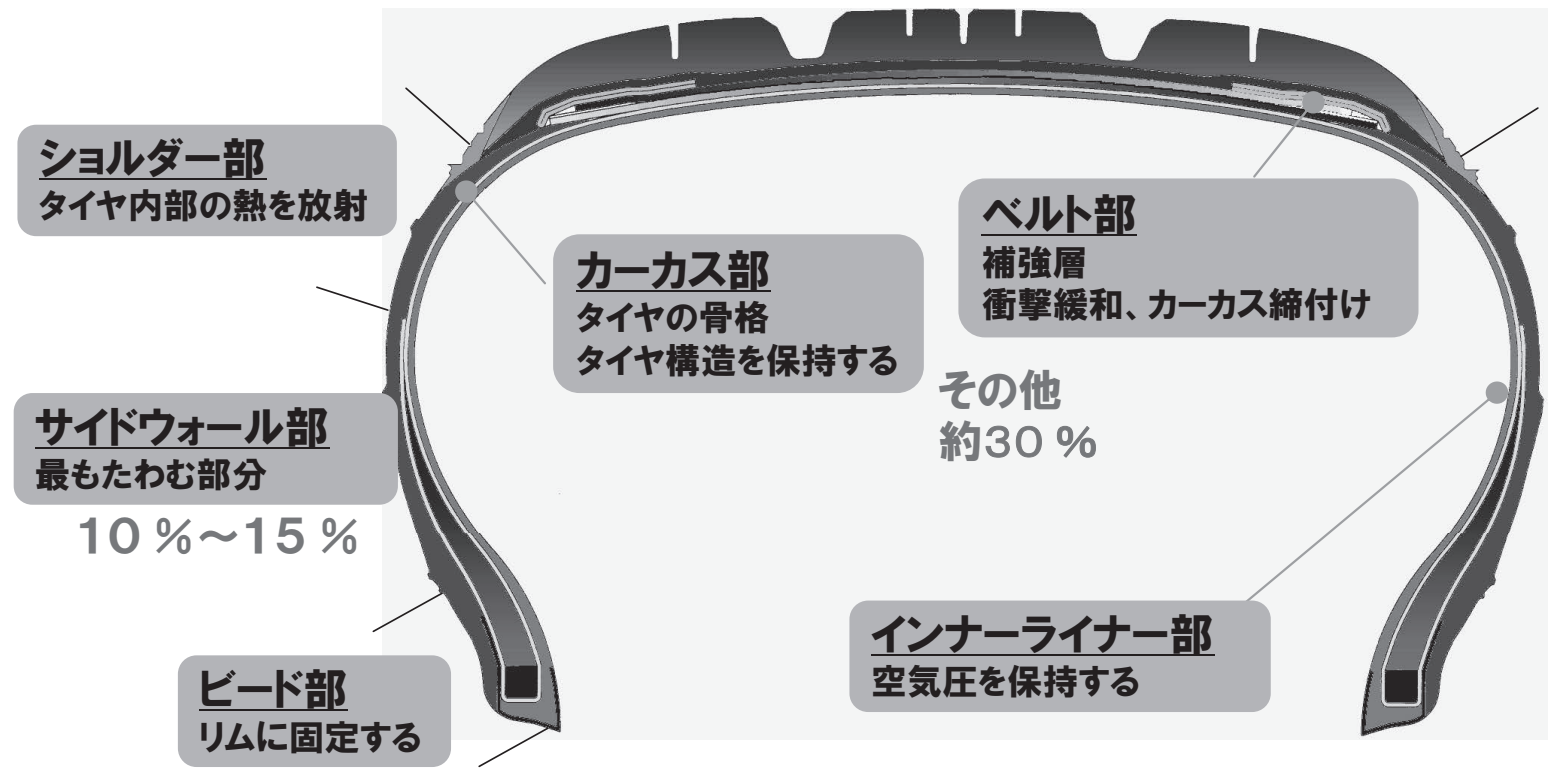

図1タイヤ構造と転がり抵抗への寄与率

表 1 低燃費夕イヤ用材料技術の変遷

\begin{tabular}{|c|c|}
\hline 1970 年代後半 & $\begin{array}{l}\text { 対米輸出自動車用低燃費タイヤ開発開始 } \\
\text { 燃費タイヤ開発競争の激化 } \\
\text { ～新規ゴム材料の開発競争へ }\end{array}$ \\
\hline 1980 年代前半 & 溶液重合 SBR 改良品の開発が始まる \\
\hline 1980 年代 & 低燃費 $\mathrm{CB}$, 反発弾性向上ゴム薬品の出現 \\
\hline 1980 年代後半 & $\begin{array}{l}\text { 末端変性 SBR および BR の出現 } \\
\quad \rightarrow \quad \text { 日本製ポリマーが世界を席巻 }\end{array}$ \\
\hline 1990 年代前半 & グリーンタイヤ（SBR/BR/ シリカ配合）の出現 \\
\hline 1990 年代後半 & $\begin{array}{l}\text { シリカ配合に拉ける技術開発が進む } \\
\text { シリカ分散剤, シリカ結合カーボン, 新規シラン } \\
\text { カップリング剂等 }\end{array}$ \\
\hline 2000 年代 & シリカ配合用末端変性ポリマー, 高分散性シリカ等 \\
\hline
\end{tabular}

が必要であることから，ミクロ構造・末端構造の制御可能 な溶液重合 SBRの開発が積極的に行われている。ミクロ 構造としては，ビニル結合量を増やすことで，湿潤路面摩 擦に効果のある $0{ }^{\circ} \mathrm{C}$ 付近の $\tan \delta$ を高く，転がり抵抗に効 果のある $50 \sim 60{ }^{\circ} \mathrm{C}$ 付近の $\tan \delta$ を低くすることができる ようになり，低然費夕イヤの性能が大きく向上している.

末端構造に関しては，初期のものは，カーボンブラック 表面への吸着を狙った末端基が主体であったが，2000年 代以降ではシリカ配合化の流れに伴い，シリカ用の末端変 性ポリマーに関する報告が増えてきている。シリカ表面に はシラノール基があり，シランカップリング剂同様，これ と作用するものが有効である。官能基としては，シラン系 の他に，アミン，カルボキシル，エポキシ等が検討されて おり ${ }^{2)}$ ，またこれらを複合（アルコキシシリル基とアミ） 基を同一末端に結合）させることでシリカ表面との反応性

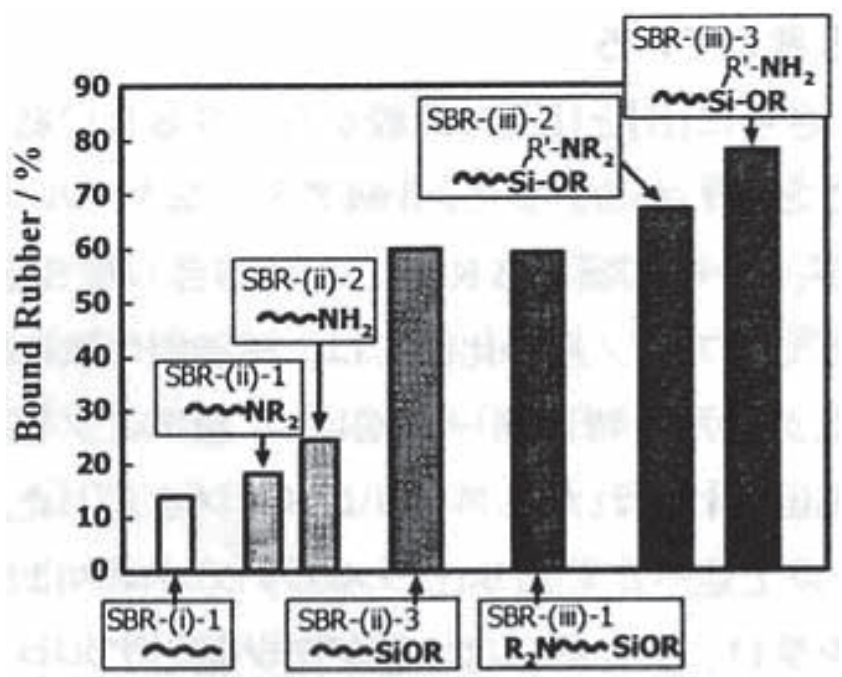

図2 末端機能化 SBR/シリカ配合未加硫ゴムのバウンドラバー量 ${ }^{3)}$

がいっそう向上したという報告例もある（図 2） ${ }^{3)}$ 。溶液 重合SBRの様な直鎖状の分子鎖では，末端は2つあるが， その両末端に官能基を付与することで，片末端の場合に対 し反発弾性が $12 \%$ 向上することが報告されている (表 2$)^{4)}$. 今後更なる性能向上が期待される.

\section{3 フィラー}

補強性・強靱化・耐摩耗性付与の観点から，フィラーと してカーボンブラックが利用されてきたが，1990年代か らタイヤトレッド向けには湿潤路面との摩擦力と低発熱の バランスが良好なシリカへの置換が進み始めた。シリカは その表面が親水性のシラノール基に覆われていることから コンパウンドへの分散性が悪い一方，湿潤路面との親和性 
表 2 多官能ポリマーの評価結果 ${ }^{4)}$

\begin{tabular}{ll|l|l|l|}
\hline & $M_{\mathrm{w}}$ & $\mathrm{ML}_{1+4} 100^{\circ} \mathrm{C}$ & Resilience \\
\hline
\end{tabular}

改善 ${ }^{2)}$, シランカップリング剂をはじめとする加工助剂の 開発でカーボンブラックでは得難いフィラー／ポリマー界 面の化学結合補強やフィラー分散制御による低発熱化・耐 摩耗性改善が得られる。 また, シリカとカーボンブラック 双方の利点を生かしたシリカ結合カーボンといったフィラ 一も利用されている ${ }^{5)}$.

最近ではシミュレーションによる物性発現メカニズム解 明や，最適なフィラー配置も着目されている ${ }^{6-9)}$ 。これら の解析には, SPring-8 - 地球シミュレータ等, 最新の分析 機器・スーパーコンピューターが活用されている.

\section{4 その他}

ポリマー・フィラー関連のほかに, 湿潤路面との摩擦改 善を狙った原料として，オレンジの皮から抽出される成分 を利用した天然系配合剤も活用されている。ポリマーへの 相溶性が高いことから，固く絡み合ったポリマーの隙間に 入り込みポリマー分子の動きを柔軟にし，路面の微細な凹 凸に追従することで摩擦性能が向上していると考えられて いる ${ }^{10)}$.

\section{3. 新素材技 術}

\section{1 新材料開発の背景}

夕イヤ特性の中で転がり抵抗の燃費性能への寄与は大き いが，性能を十分に発揮するには適正空気圧を保つことが 重要である。図 3 は2000ccの乗用車で空気圧が50kPa不足 した場合の走行形態と燃費悪化率を示した例であるが，使 用状況によって $2.5 \%$ ～4.8\%も燃費が悪化するというデー 夕である. 空気圧不足の影響は燃費悪化だけに留まらず, 高速道路における JAFの出動理由ワーストは夕イヤのパ

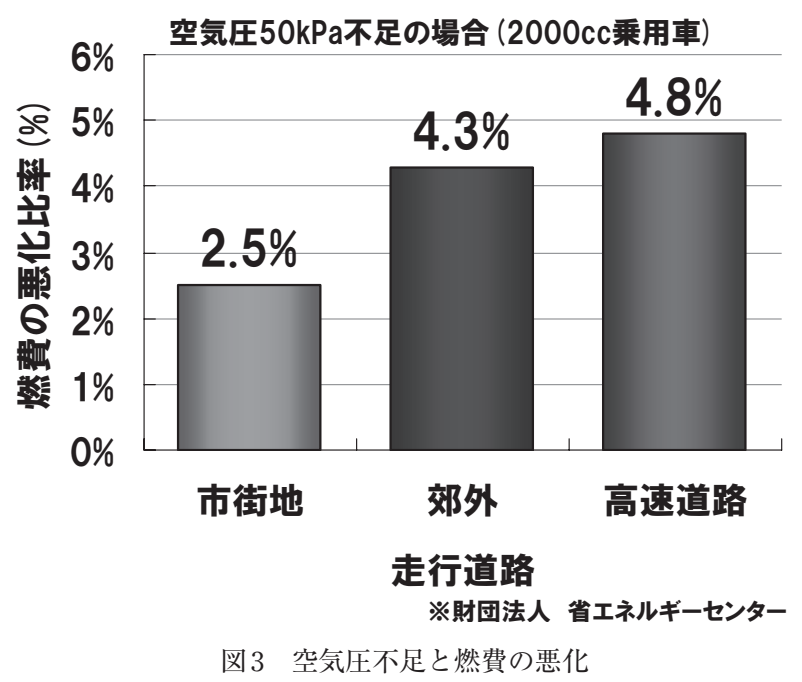

ンク，バースト，空気圧不足であることから安全性にも大 きな影響を与えている. 夕イヤ業界ではメーカーの責務と して空気圧の重要性を訴え，月に1度の空気圧点検を推奨 するキャンペーンを実施するなどユーザーの意識向上に努 めているが，マーケティングリサーチの 1 例では $70 \%$ 以上 のユーザーが2ヶ月以上空気圧点検を実施せず，そのうち 半数以上は 6 ケ月以上実施しないというデータがある. ま た，同様の調査例で指定空気圧自体を知らないユーザーが 約半数を占めるとのデータもあり, 環境意識の高さに反し てタイヤの空気圧に関する関心の低さが窥える。実際の路 上調査でも指定空気圧に満たない車が約 $20 \%$ 走行していた データがあり, 空気圧不足による燃費の悪化が懸念される. 夕イヤの空気圧を維持するのは夕イヤの中でもインナーラ イナーと呼ばれる部材の役割で (図 1), 従来はゴムの中 で最も空気を透過しにくいブチルゴム主体のコンパウンド が用いられてきた。タイヤの空気圧保持性能を高めるには 
従来インナーライナーの厚みを増す方法があるが，重量増 による燃費への悪影響があり，保持性能の目標によるが 1\%〜 6\%悪化するという試算がある。またブチルゴムは石 油資源由来の合成ゴムであって省資源化が求められる原料 であるため, 空気圧保持性能と省資源化を両立する新たな 方法が必要となっている。

\section{2 インナーライナー用DVA技術}

石油由来原料を低減し，且つ空気圧保持性能を高めるた めに従来のゴムコンパウンド技術から脱却し, 空気バリア 性に優れた樹脂の利用検討を進めてきた。空気バリア性樹 脂としては例えば食品包装等で利用されているナイロンや エチレンビニルアルコールが挙げられ (図4), 当初はこ れら樹脂フィルムをそのままインナーライナー素材として 利用評価した。しかしバリア性樹脂の従来用途に比べると タイヤ用途では高い動的ひずみに耐える性能，それも二桁 以上大きい繰り返し回数での疲労耐久性能が求められる. しかもタイヤは市場で想定される以上の最も過酷な方法で 試験されるため，バリア性樹脂単体フィルムでは試験後に 材料破壊する問題があった。そこで着目したのがゴム／樹 脂動的架橋型熱可塑性エラストマー材料（以降 DVA, Dynamically Vulcanized Alloy) の技術である。DVAは 樹脂が海，ゴムが島の海島構造を持ち，樹脂の特性とゴム の柔軟性をバランスさせることができる。一般にバリア性 樹脂が極性材料であるのに対し，ゴムは非極性であるため 良好な DVA を得るには相溶化手法が必要になる。また， 樹脂には夕イヤの加硫温度で溶解しない融点が求められる

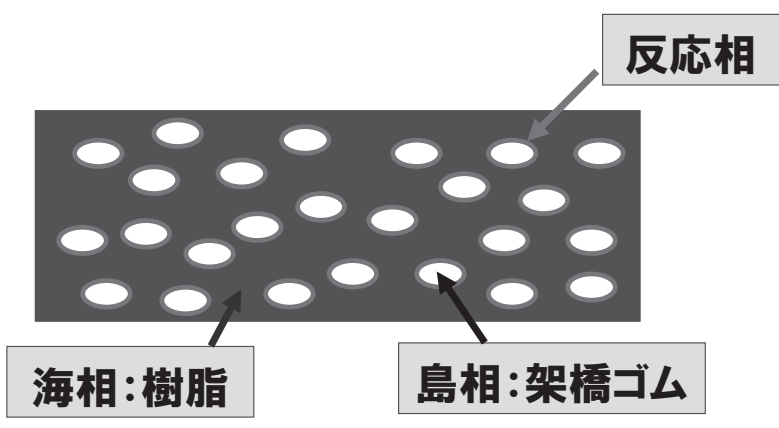

図 5 タイヤ用熱可塑性エラストマーの模式図
がゴムは熱に弱いため，熱劣化を最小化する配合手法や混 練条件が求められる。ささらには前述の通り高い耐久性が求 められるためゴムを可能な限り多量に配合し，柔軟性を高 める必要がある。これら課題を解決し, 得た DVA は図 5 のように樹脂が海相，架橋ゴムが島相になっており，ゴム は樹脂と反応することで相溶性が改善されて樹脂中に微細 分散している. 図6はDVA と原料樹脂，ゴムの応力ひず み挙動を示したものであるが，ゴムに比べて若干弾性率が 高いものの樹脂に比べると非常に低く，柔軟であることが 分かる、ゴムを高体積率配合することで海相が固い樹脂で あってもゴムに近い柔軟性を得ることができるのである。 一方樹脂の特性としては空気バリア性が求められるが，図 7 に示した通りゴムを配合することで樹脂単体と比べた空

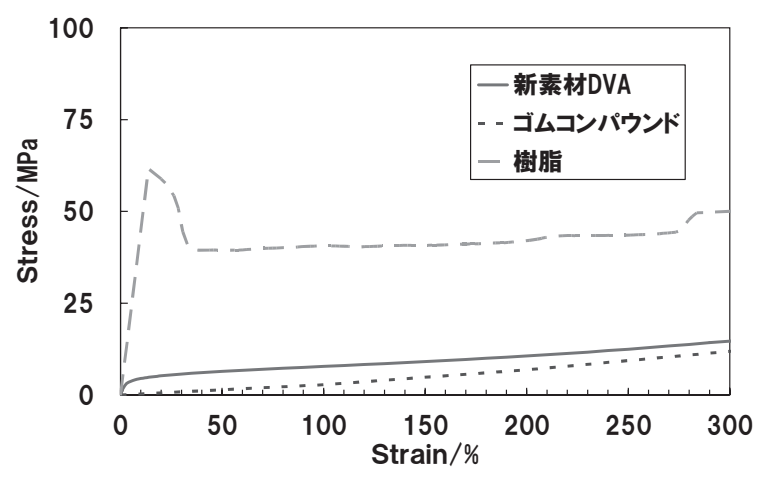

図6＼cjkstart新素材DVA と樹脂およびゴムの応力ひずみ挙動

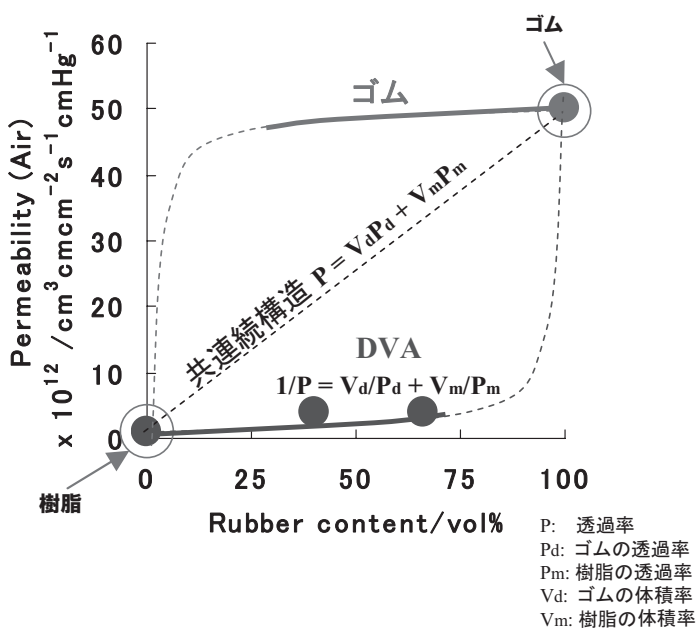

図7＼cjkstart新素材DVAにおけるゴム量と空気透過性の関係

\begin{tabular}{|c|c|c|c|}
\hline & & $\begin{array}{c}\text { Permeability*1 }\left(\mathrm{O}_{2}\right) \\
\times 10^{13} / \mathrm{cm}^{3} \mathrm{cmcm}^{-2} \mathrm{~s}^{-1} \mathrm{~Pa}^{-1}\end{array}$ & $\begin{array}{l}\text { Tensile Modulus } \\
\text { / } \mathrm{MPa}\end{array}$ \\
\hline \multirow{2}{*}{ 従来技術 } & 天然ゴム & 17.6 & $5 * 2$ \\
\hline & ブチルゴム & 0.977 & $3 * 2$ \\
\hline \multirow{2}{*}{ 低透過性樹脂 } & ナイロン & 0.0285 & $1500-3000 * 1$ \\
\hline & エチレンビニルアルコール & 0.00665 & $2000-4000 * 3$ \\
\hline
\end{tabular}

図4＼cjkstart従来ゴム材料と低透過性樹脂の酸素透過性と引張弾性率 
気バリア性は悪化するもののその比率は小さく，ゴムが高 体積率配合されていても樹脂に近い空気バリア性能を発現 することが分かる．DVAにすることでバリア性と柔軟性 という本来相反する特性をうまくバランスさせることがで きるのである.

\section{3 新素材インナーライナー}

良好な特性バランスを得たDVAは一般の樹脂と同じ技 術を用いて省エネルギーで成形することが可能である。樹 脂の成形技術によりDVAをフィルムに成形し, 試作タイ ヤを作製して室内および実車評価したところ，一部厳しい 条件でDVAの故障が発生した。従来評価項目では問題な かったものの，前例のない新素材に対する十分な評価を行 うために，いじめ試験と呼ぶ様々な厳しい試験を追加実施 し，その中の一部で新素材インナーライナーに故障が発生 したのである．基本的に柔軟性と耐久性は相関があり，柔 らかければ耐久性が向上するためにゴムを高体積率充填し たが，故障の要因解析を行う中で図8のようにDVA中の ゴム分散粒径も疲労耐久性に大きく影響し，微細分散する ほど向上することが明らかになった．充填可能なゴムの体 積率は単純にはゴムと樹脂の粘度比と相関があり ${ }^{11)}$ ，樹 脂の粘度が低いほど高充填することができる。一方, 分散 したゴムの粒径も粘度比と相関し，粘度比が 1 に近いほど 分散粒径は小さくなることが知られている ${ }^{12)}$ 。このよう な関係からゴムの微細分散と高充填は基本的に背反する要 素となるが，タイヤ試験の結果からこれらを高いレベルで
両立させる必要があることが分かり，DVAの配合だけで なく，混合プロセスについても詳細な条件検討と工夫を施 して改善を行った. 以上のようにして材料技術, 混合技術, 評価技術を改良し続けて高い空気バリア性能と耐久性を両 立したDVAインナーライナーは次世代エコタイヤ技術と して2009年東京モーターショーで発表し, 以降エコフラ ッグシップタイヤへの採用を中心に商品展開を進めてき た. 従来インナーライナーよりも薄くしながらタイヤの空 気圧保持性能の向上に貢献しており，2011年に発表した 新しい夕イヤ商品では従来インナーライナーの約 5 分の 1 の厚みの新素材インナーライナーを採用し, 従来品に比べ て約 30\%の空気圧保持性能改善を達成した（図 9)。環境 性能と安全性能を向上させる技術として商品展開を進める 一方で，自然な空気漏れに起因した燃費の悪化や故障，事 故をなくすことを究極の目標としてさらなる新素材インナ ーライナー技術の改良に取組んでいる.

\section{4. お わ り に}

近年の環境性能の向上は転がり抵抗への寄与が大きいト レッドゴムのシリカ配合技術が中心であり, 従来行われて きたシランカップリング剤の検討だけでなく，末端変性ポ リマーや高度なシミュレーション技術を駆使したナノレベ ルからの材料設計が進められている。 その一方で空気圧保 持機能を向上させるため, 樹脂を使った新たな素材を開発, 高い環境性能を維持する取り組みも進められている。今後 さらに新素材技術が改良され，自然な空気漏れを最低限に

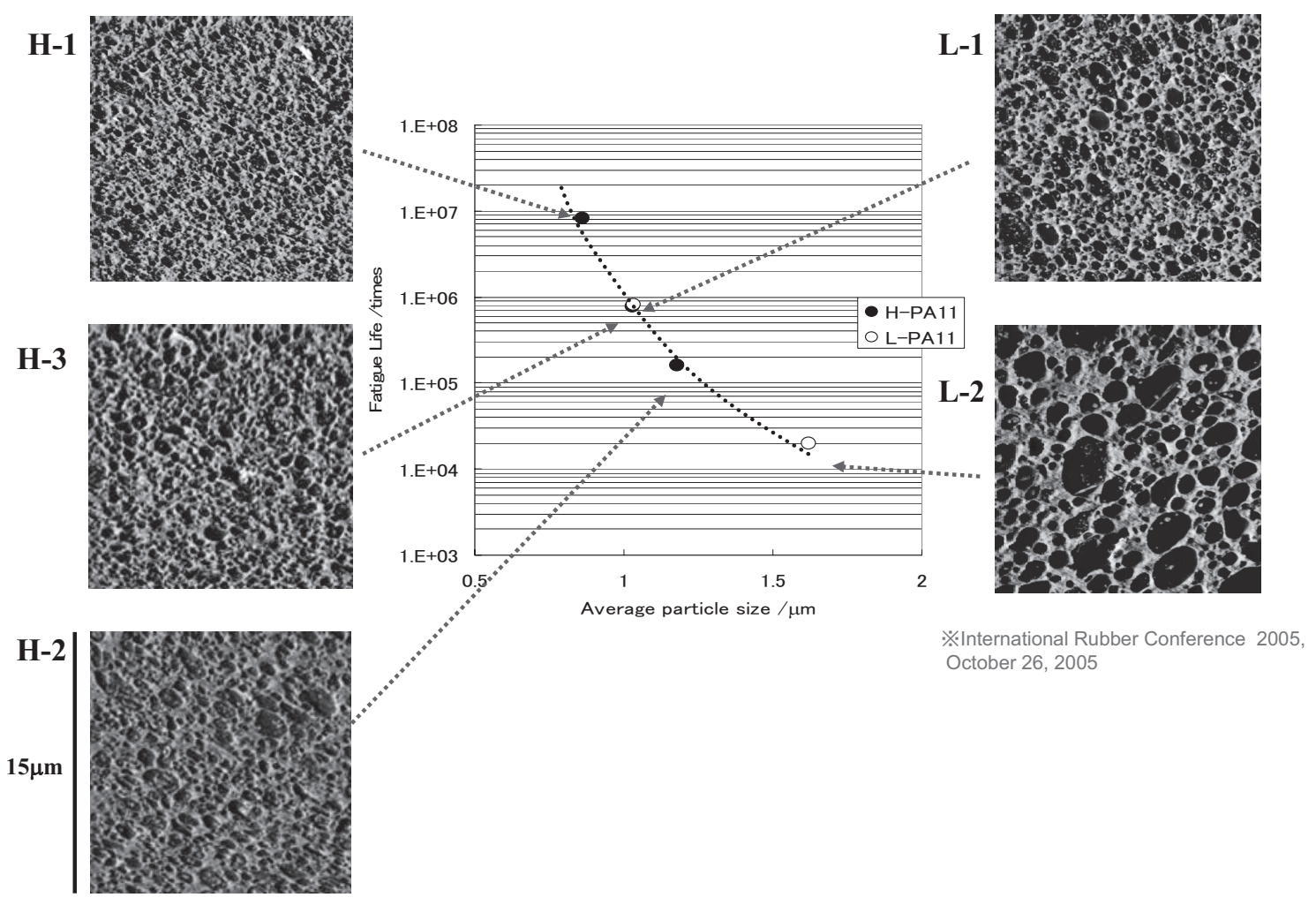

図8 DVA中のゴム平均粒径と疲労耐久性の関係 


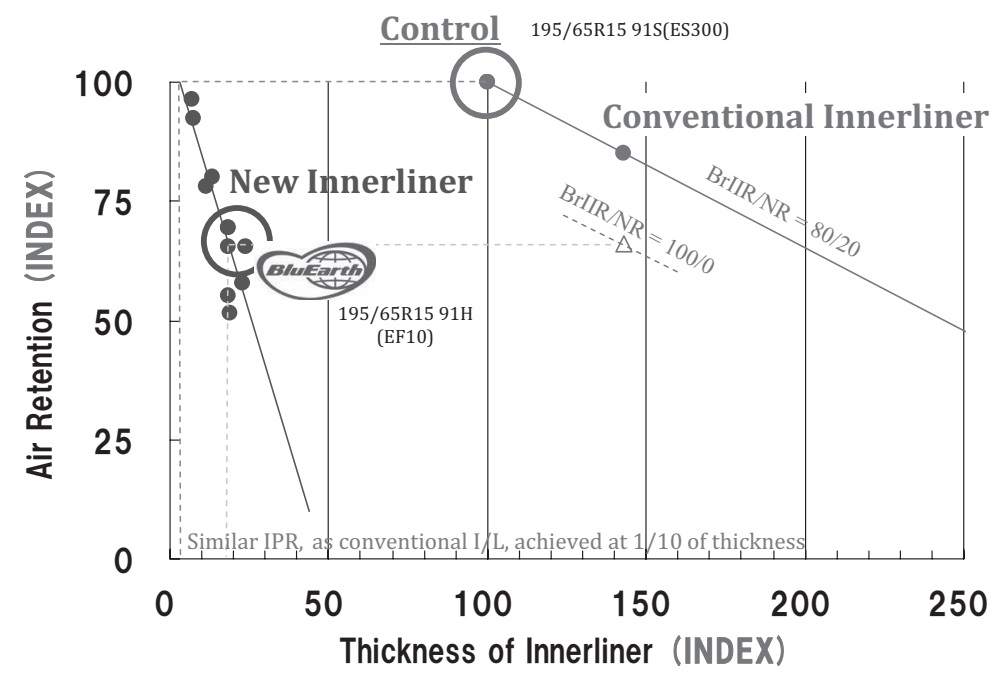

図9 従来素材および新素材を用いたタイヤの空気圧保持性能

抑えることができたとしても，タイヤ空気圧の管理はドラ イバーの責務であり, 定期的なチェックが必要であること を明記しておきたい，近年は空気圧を常時監視する夕イヤ 空気圧モニタリングシステム（TPMS）装着の動きも広が つており，低圧走行による重大事故が問題視されたアメリ カでは 2007 年に，4輪車両の新車すべてで装着が義務化さ れている．国内においても低価格で追加装着できるシステ ムが市販化されつつあり，手軽に管理できるようになって きている。本稿により環境に優しい夕イヤを選ぶだけでな く，その性能を維持するための夕イヤ空気圧管理の重要性 を再認識して頂き，関心が高まることを期待している.

\section{References}

1 ) Yokohama Rubber Co., Ltd. Ed., “Jidosha yo Tire no Kenkyu”, Sankaido, Tokyo (1995)

2) Fujimaki, T.; Morita, K.: Nippon Gomu Kyokaishi, 71, 562 (1998)

3 ) Tadaki, T.: Kobunshigakkai Tokai Symposium, January 2012, Nagoya

4 ) http://www.sumitomo-chem.co.jp/rd/report/theses/docs/20111J_3.pdf

5 ) Kawazura, T.: Nippon Goти Kyokaishi, 73, 379 (2000)

6 ) Koishi, M.; Miyashita, N.; Amino, N.: $48^{\text {th }}$ Nippon Gakujutsu
Kaigi Zairyo Kenkyu Rengo Koenkai, October, 2004, Tokyo

7 ) Koishi, M.: Jidoshagijutsu, 60 (6), 55 (2006)

8 ) Yamaguchi, K.; Sato, Y. ; Yamamoto, A. ; Akutagawa, K. ; Heguri, H. ; Jinnai, H.: 26-G2-13, IRC-2005, Yokohama, 2005.

9 ) http://www.jamstec.go.jp/es/jp/project/sangyou_report/ H22_SRI_jp.pdf

10) Hata, H.: Gekkan Tire, 39 (5), 60 (2007)

11) Paul, D. R.: Barlow, J. W.: J. Macrmol. Sci - Rev. Macromol. Chem.: 18, 109 (1980)

12) Wu, S.: Polym. Eng. Sci:: 27, 335 (1987)

\section{日本語表記参考文献}

1 ）横浜ゴム株式会社編集：自動車用タイヤの研究，山海堂，東京 (1995)

2 ）藤巻達雄，森田浩一：日本ゴム協会誌，71，562（1998）

3 ) 但木稔弘：高分子学会東海シンポジウム（2012 年1月名古屋）

4 ) http://www.sumitomo-chem.co.jp/rd/report/theses/docs/20111J_3.pdf

5 ）川面哲司：日本ゴム協会誌，73，379（2000）

6 ) 小石正隆，宮下直士，網野直也：第 48 回日本学術会議材料研究 連合講演会（2004年10月東京）

7 ) 小石正隆：自動車技術，60(6), 55 (2006)

9 ) http://www.jamstec.go.jp/es/jp/project/sangyou_report/ H22_SRI_jp.pdf

10）畑 寛：月刊タイヤ，39（5)，60（2007） 